\title{
PENGEMBANGAN CD INTERAKTIF PEMBELAJARAN MATEMATIKA PADA MATERI STATISTIKA
}

\author{
Rr. Tri Utaminingsih ${ }^{1}$, Akhmad Nayazik ${ }^{2}$, Arie Wahyuni ${ }^{3}$ \\ triutaminingsih3@gmail.com \\ ${ }^{1,2,3}$ Universitas Ivet
}

\begin{abstract}
The purpose of this study is to get results of interactive CD development valid, practical and effective statistical material. The type of this research is development research which refers to ADDIE (Analysis, Desigh, Development, Implementation aand Evaluatin). The subject of this research is xi grade of SMK Bhakti Praja 2 Batang. The instrument used in this research is (1) media expert evaluation questionnaire (2) material expert evaluation questionmire (3) student response questionnaire (4) student evaluation questions. The method used in gathering the data is, by doing observations, questionnaires, tests, and documentation. The results of this study show the validty quality of the interactive $\mathrm{CD}$ meetr valid criteria shown by media experts who obtained and average score of 3,8 from maximum score 4 which is good, while material experts get 4,1 from maximum score 5 which means good. Quality of practicality of learning devices practical criteria indicate by the average score of student 4,01 from maximum score 5 which means good. Quality of effectiveness of learning devices in terms of students' mathematical communication skills meet practical criteria shown by the percentage of students completeness $87,5 \%$ which means good. Of the 32 student, there are 28 students who had completed grads.
\end{abstract}

Key words: Development, Interactive CD, ADDIE model.

\section{Abstrak}

Tujuan penelitian ini adalah untuk memperoleh hasil pengembangan CD interaktif materi statistika yang valid, praktis, dan efektif. Jenis penelitian ini adalah penelitian pengembangan dengan mengacu pada model pengembangan ADDIE (Analysis, Design, Development, Implementation and Evaluation). Subjek penelitian ini adalah siswa kelas XI SMK Bhakti Praja 2 Batang. Instrumen yang digunakan pada penelitian ini adalah (1) angket evaluasi ahli media (2) angket evaluasi ahli materi (3) angket respon siswa (4) soal evaluasi siswa. Metode yang digunakan dalam mengumpulkan data yaitu dengan melakukan observasi, angket, tes, serta dokumentasi. Hasil penelitian ini menunjukkan kualitas kevalidan CD Interaktif memenuhi kriteria valid ditunjukkan Ahli media memperoleh skor rata-rata 3,8 dari skor maksimal 4 yang berarti baik, sedangkan dari Ahli materi memperoleh 4,1 dari skor maksimal 5 yang berarti baik. Kualitas kepraktisan CD Interaktif memenuhi kriteria praktis ditunjukkan oleh skor rata-rata respon siswa yaitu 4,01 dari skor maksimal 5 yang berarti baik. Kualitas keefektifan CD Interaktif ditinjau dari kemampuan komunikasi matematis siswa memenuhi kriteria efektif ditunjukkan oleh persentase ketuntasan siswa yaitu $87,5 \%$ yang berarti baik dari 32 siswa mendapatkan nilai yang tuntas ada 28 siswa.

Kata kunci: Pengembangan, CD Interaktif, Model ADDIE.

\section{ARTICLE HISTORY:}

Received: 21 Maret 2020, Revised: 2 April 2020,

Accepted: 4 April 2020, Onlinefirst: 11 April 2020 


\section{PENDAHULUAN}

Pendidikan merupakan sesuatu yang sangat penting pada masa sekarang ini, karena pendidikan merupakan kebutuhan yang mutlak harus dipenuhi sepanjang hayat bagi umat manusia. Tanpa pendidikan sama sekali mustahil suatu kelompok manusia dapat hidup dan berkembang sejalan dengan aspirasi (cita-cita) untuk maju, sejahtera dan bahagia (Fuad Ihsan, 2001). Untuk itu, seluruh warga negara Indonesia harus mengenyam pendidikan, hal ini tentu selaras dengan UUD 1945 pasal 31 ayat 1 yang berisi: "Tiaptiap warganegara berhak mendapat pengajaran".

Dari hasil observasi yang dilakukan peneliti, terlihat bahwa penggunaan media pembelajaran matematika sangat minim. Hal ini juga menjadi salah satu penyebab mengapa siswa kurang tertarik dengan matematika itu sendiri. Padahal dengan menggunakan media pembelajaran siswa akan lebih tertarik dengan matematika serta memudahkan siswa dalam memahami konsep-konsep matematika. Media pembelajaran berguna untuk memperjelas penyajian materi (Arief S Sadiman dkk 2009).

Pentingnya penggunaan media dalam kegiatan pembelajaran matematika belum disadari oleh para guru. Penggunaan media pada kegiatan pembelajaran bertujuan untuk mempermudah guru dalam menyampaikan materi. Hal ini juga dikemukakan oleh Heinich, dkk dalam bukunya Instructional Media and Technology for Learning (Suherman, dkk 2003) menyatakan bahwa keseluruhan sejarah media dan teknologi telah mempengaruhi pendidikan. Pada masa kini, komputer telah memberikan pengaruh sangat kuat terhadap pembelajaran. Alat-alat demikian menawarkan kemungkinan untuk menjadi lebih baik dalam proses belajar mengajar, namun guru akan menjadi berbeda ketika menggunakan media dalam pembelajarannya.

Media dapat diartikan sebagai "perantara" yang menghubungkan antara guru atau instruktur dengan siswa. Media dapat digunakan untuk mendukung terciptanya proses pembelajaran yang efektif, efisien, dan menarik (Pribadi, 2009). Ada berbagai macam media yang dapat digunakan guru untuk mendukung kegiatan pembelajaran agar berlangsung sesuai dengan tujuan yang diharapkan. Ragam media pembelajaran yang dapat digunakan diantaranya: teks, audio, video, media permanen, komputer, dan jaringan (internet).

Materi pada pokok bahasan statistika dapat divisualisaikan dengan menggunakan perangkat-perangkat lunak (software) pada komputer. Untuk itu, peneliti tertarik untuk 
melakukan penelitian dengan mengembangkan CD Interaktif pembelajaran matematika materi statistika.

Kebiasaan guru yang hanya menjelaskan dengan contoh manual di papan tulis menjadi salah satu faktor utama. Sesuai dengan pernyataan siswa bahwa materi statistika mudah tetapi jika model pembelajaran yang digunakan selalu sama maka siswa cepat merasa bosan. Pernyataan siswa ini juga diperkuat dengan pernyataan guru matematika disekolah tersebut bahwa dalam persiapannya untuk menggunakan media pembelajaran komputer memerlukan waktu yang lama dan penyampaian materi tidak sesuai dengan alokasi waktu.

Kelebihan dari CD Interaktif ini adalah bahan ajar yang menarik dengan menayangkan gambar, teks, suara, dan memudahkan penggunanya untuk memahami materi karena dirancang secara lengkap mulai dari petunjuk penggunaannya hingga penilaian (Prastowo, 2012). Didalamnya memuat masalah-masalah yang ada dikehidupan sehari-hari sehingga siswa dapat memahami dengan baik, terdapat contoh-contoh soal dan latihan soal-soal yang bervariasi dan kegiatan individu maupun kerjasama dalam kelompok. Pembelajaran berbasis multimedia interaktif dengan melalui CD Interaktif sebagai alatnya, karena dengan menggunakan animasi-animasi diprogram ini, materi statistik dapat divisualisasikan. Dengan menggunakan media ini, siswa dapat langsung melihat simulasi dan demonstrasi yang menyerupai kejadian sebenarnya, sehingga siswa dapat menangkap konsep-konsep statistik dengan baik dan benar serta dapat diterapkan dalam kehidupan sehari-hari. Selain itu, media ini juga untuk memaksimalkan sarana dan prasana yang ada di sekolah tersebut. Dalam mengembangkan media pembelajaran interaktif ini, peneliti memakai model pengembangan ADDIE (Analysis, Design, Development, Implementation, Evaluation).

Dari permasalahan di atas, peneliti tertarik untuk mengembangkan suatu media yang menarik dan menyenangkan bagi siswa pada pembelajaran matematika materi statistika. Berdasarkan penelitian sebelumnya yang dijadikan acuan maka peneliti menganggap model ADDIE tepat untuk mengatasi permasalahan-permasalahan yang dihadapi siswa saat belajar matematika. Pengembangan media tersebut diharapkan meningkatkan prestasi belajar peserta, minat dan motivasi siswa dalam kegiatan belajar didalam kelas. Peneliti akan menerapkan model ADDIE didalam media berupa CD interaktif. 
Uraian di atas telah menjelaskan pentingnya pengembangan media pembelajaran yang baik dan inovatif. Hal tersebut yang menjadi latar belakang untuk mengembangkan suatu media yang belum pernah digunakan oleh guru matematika di SMK Bhakti Praja 2 Batang. Pengembangan media ini merupakan hal yang baru di SMK Bhakti Praja 2 Batang, khususnya untuk materi statistika ini.

Berdasarkan hasil observasi di SMK Bhakti Praja 2 Batang didapatkan bahwa siswa mengalami kesulitan dalam memahami materi statistika yang diajarkan karena guru sering menggunakan model pembelajaran yang biasa dan tidak dilengkapi dengan media yang menunjang materi tersebut. Siswa menganggap matematika kurang menarik karena hanya berisi angka dan rumus. Hal tersebut berdampak pada motivasi belajar siswa sehingga pada akhirnya akan mempengaruhi prestasi belajar matematika. Siswa menginginkan sebuah media pembelajaran yang menarik, mudah dipahami, masalah masalah yang disajikan berkaitan dengan kehidupan sehari-hari, memuat contoh soal, dan latihan soal yang bervariasi. Penggunaan fasilitas berupa komputer atau LCD pada pembelajaran di kelas belum maksimal, padahal jika sarana dan prasarana tersebut dimanfaatkan secara maksimal maka akan membantu meningkatkan motivasi belajar siswa. Teknologi informasi dan grafis menawarkan beragam solusi untuk mengatasi rendahnya motivasi belajar siswa. Hal tersebut berupa pembuatan media pembelajaran berbasis komputer pada pembelajaran matematika. Selain itu, fasilitas di sekolah sudah memadai untuk melaksanakan pembelajaran berbasis komputer. Siswa menganggap bahwa matematika itu sulit, tidak menyenangkan, membosankan, rumit, banyak rumus, dan lain-lain. Perlu adanya media yang mendukung siswa untuk memvisualkan materi yang disampaikan guru. Pemanfaatan sarana dan prasarana yang disediakan sekolah kurang dimanfaatkan secara maksimal oleh guru sehingga kurang mendukung pembelajaran di kelas.

Adapun tujuan yang ingin dicapai dalam penelitian ini adalah Untuk memperoleh hasil pengembangan CD Interaktif materi statistika yang valid, praktis, dan efektif.

\section{METODE PENELITIAN}

Metode penelitian dan pengembangan atau dalam bahasa Inggrisnya Research and Development (R\&D) adalah metode penelitian yang digunakan untuk menghasilkan produk tertentu, dan diuji keefektifannya. (Sugiyono, 2008). 
Model pengembangan CD interaktif dengan model ADDIE yang dikembangkan oleh Dick dan Carey (1978), meliputi Analysis, Design, Development, Implementation, dan Evaluation. Tahap pengembangan CD interaktif tersebut dapat diuraikan sebagai berikut.

\section{Tahap Analysis (Analisis)}

Tahap ini bertujuan untuk menentukan mata pelajaran, analisis KI, KD, analisis kebutuhan media, analisis kondisi, analisis tujuan, analisis kurikulum, dan materi, analisis tingkat kemampuan dan karakteristik sasaran pengguna.

2. Tahap Design (Desain)

Tujuan dari tahap ini adalah merancang butir-butir materi yang akan disajikan, menyusun pernyataan tujuan produk, memetakan tujuan dengan unsur media yang dibutuhkan, perancangan model, penyusunan naskah materi, pembuatan storyboard media, dan pengumpulan bahan-bahan yang dibutuhkan dalam pengembangan media.

3. Tahap Development (Pengembangan)

Pada tahap ini bertujuan untuk mngumpulkan materi, penggarapan/pembuatan media menggunakan Software Macromedia Flash. Pengujian dan distribusi, pengembangan instrumen evaluasi produk, evaluasi ahli isi, media, dan desain pembelajaran, perbaikan produk berdasarkan saran dari para ahli, uji coba produk pada siswa perorangan dan kelompok kecil, uji coba produk pada guru mata pelajaran matematika, perbaikan produk berdasarkan saran guru mata pelajaran.

4. Tahap Implementation (Implementasi)

Tujuan dari tahap ini adalah melakukan uji coba lapangan terhadap CD Interaktif yang dikembangkan, penilaian oleh ahli media, ahli materi, dan praktisi lapangan serta pelaksanaan uji coba terbatas.

5. Tahap Evaluation (Evaluasi)

Pada tahap ini dilakukan analisis hasil penilaian dari ahli dan siswa. Kualitas media pembelajaran ini dinilai berdasarkan dua kriteria yaitu kevalidan dan kepraktisannya.

\section{Instrumen Pengumpul Data}

Terdapat tiga macam data yang akan diperoleh dalam penelitian ini yaitu dengan observasi, tes, dan angket respon siswa. Observasi dilakukan dengan cara pengamatan terhadap aspek-aspek yang dibutuhkan yang terkait dengan pengembangan CD Interaktif. Tes hasil belajar siswa digunakan untuk mengukur tingkat ketuntasan belajar siswa. 
Ketuntasan tes hasil belajar siswa akan digunakan sebagai indikasi keefektifan media CD interaktif pembelajaran berbasis komputer. Angket merupakan teknik pengumpulan data yang dilakukan dengan cara memberi seperangkat pertanyaan atau pernyataan tertulis kepada responden untuk dijawabnya (Sugiyono, 2012). Angket validasi diberikan kepada ahli media dan ahli materi. Angket tersebut berfungsi untuk mengetahui nilai validasi media baik dari segi media maupun segi materi yang dimuat dalam media. Sedangkan angket responden diberikan kepada siswa untuk mengetahui respon siswa dalam menggunakan media yang dikembangkan peneliti.

\section{Teknik Analisis Data}

Teknik analisis data yang digunakan dalam penelitian ini adalah

1. Kevalidan Produk

Data dari lembar validasi ahli media dan materi akan diperoleh kritik dan saran perbaikan terhadap CD interaktif. Selain itu, akan diperoleh pula penilaian untuk menentukan kevalidan CD interaktif. Untuk menganalisis data tersebut akan digunakan rumus dibawah ini :

$$
\mathrm{V}=\frac{\sum X}{N}
$$

(Sugiyono, 2010)

Keterangan:

$\mathrm{V}=$ Validitas Produk

$\sum X=$ Jumlah skor

$N=$ Jumlah responden

Kemudian mengkonversi rata-rata sesuai dengan tabel 1 berikut ini:

Tabel 1. Kriteria Validitas Produk

\begin{tabular}{ll}
\hline Rentang Kategori Skor & Penafsiran \\
\hline $1.00 \leq \mathrm{V} \leq 1.79$ & Sangat Tidak Baik/Sangat Rendah \\
\hline $1.79 \leq \mathrm{V} \leq 2.59$ & Tidak Baik/Rendah \\
\hline $2.59 \leq \mathrm{V} \leq 3.39$ & Cukup/Sedang \\
\hline $3.39 \leq \mathrm{V} \leq 4.19$ & Baik/Tinggi \\
\hline $4.19 \leq \mathrm{V} \leq 5.00$ & Sangat Baik/Sangat Tinggi \\
\hline
\end{tabular}

2. Kepraktisan Produk

Kepraktisan produk dapat diketahui melalui lembar angket respon siswa. Data dari lembar angket respon siswa dimaksudkan untuk mengetahui bahwa produk tersebut 
dapat dinyatakan praktis dan tidaknya. Selain itu, akan diperoleh pula kritik dan saran perbaikan terhadap CD interaktif. Untuk menganalisis data tersebut akan digunakan rumus dibawah ini :

$$
P=\frac{\sum X}{N}
$$

(Sugiyono, 2010)

Keterangan:

$P \quad=$ Kepraktisan Produk

$\sum X=$ Jumlah skor

$N=$ Jumlah responden

Kemudian mengkonversi rata-rata sesuai dengan tabel 2 berikut ini:

Tabel 2. Kriteria Angket Respon Siswa

\begin{tabular}{ll}
\hline Rentang Kategori Skor & Penafsiran \\
\hline $1.00 \leq \mathrm{P} \leq 1.79$ & Sangat Tidak Baik/Sangat Rendah \\
\hline $1.79 \leq \mathrm{P} \leq 2.59$ & Tidak Baik/Rendah \\
\hline $2.59 \leq \mathrm{P} \leq 3.39$ & Cukup/Sedang \\
\hline $3.39 \leq \mathrm{P} \leq 4.19$ & Baik/Tinggi \\
\hline $4.19 \leq \mathrm{P} \leq 5.00$ & Sangat Baik/Sangat Tinggi \\
\hline
\end{tabular}

\section{Keefektifan Produk}

a. Ketuntasan

Hasil belajar siswa dikatakan tuntas nilai siswa dapat menacapai KKM yang telah ditetapkan yaitu 70 .

Kriteria: Terima $\mathrm{H}_{0}$ jika $t_{\text {hitung }}>\mathrm{t}_{\text {tabel }}$ dengan taraf signifikan yang ditetapkan peneliti sebesar $5 \%$.

Berikut ini hasil perhitungan $t_{\text {hitung }}$

$$
t=\frac{\bar{x}-\mu_{o}}{\frac{s}{\sqrt{n}}}
$$

(Sudjana, 2005)

b. Perbedaan rata - rata tes awal dan tes akhir 
Rumus yang digunakan :

$$
\mathrm{t}=\frac{d}{\frac{s}{\sqrt{n}}}
$$

(Sugiono, 2012)

$$
\begin{aligned}
& \text { Keterangan : } \\
& \mathrm{d}=\text { rata }- \text { rata selisih nilai pre-test dan post-test } \\
& \mathrm{s}=\text { Simpangan Baku } \\
& \mathrm{n}=\text { jumlah sampel }
\end{aligned}
$$

\section{HASIL DAN PEMBAHASAN}

Pada penelitian ini dilakukan pengembangan $\mathrm{CD}$ Interaktif pembelajaran matematika pada materi statistika menggunakan pendekatan kontekstual dengan berorientasi pada kemampuan komunikasi matematis siswa SMK kelas XI. Pengembangan CD Interaktif pembelajaran matematika pada materi statistika menggunakan pendekatan kontekstual dikembangkan melalui 5 tahapan pengembangan yaitu analysis (analisis), design (perencanaan), development (pengembangan), implementation (pelaksanaan), dan evaluation (evaluasi). Deskripsi hasil penelitian yang telah diuraikan sebelumnya memaparkan langkah-langkah pengembangan CD Interaktif dan hasil yang diperoleh. Hasil dari pengembangan berupa produk akhir telah diuji kevalidan, kepraktisan, dan keefektifannya. Beberapa hal yang menjadi temuan dalam penelitan CD Interaktif pembelajaran matematika pada materi statistika menggunakan pendekatan kontekstual berorientasi pada kemampuan komunikasi matematis siswa adalah sebagai berikut:

a. Kevalidan

Produk berupa CD Interaktif matematika yang telah dikembangkan memenuhi kriteria valid berdasarkan hasil penilaian oleh dosen.

1. Validasi Media oleh Ahli Media

Ahli media adalah validator yang dipilih untuk menilai media CD interaktif yang dikembangkan dari aspek media. Penilaian oleh ahli media tersebut dilakukan 
dengan menggunakan lembar penilaian media CD interaktif oleh ahli media. Berdasarkan total skor rata-rata yaitu 3,8 diperoleh kevalidan dengan kriteria valid.

2. Validasi Media oleh Ahli Materi

Ahli materi adalah validator yang dipilih untuk menilai media CD Interaktif yang dikembangkan dari aspek materi. Penilaian oleh ahli materi tersebut dilakukan dengan menggunakan lembar penilaian media $\mathrm{CD}$ Interaktif oleh ahli materi. Berdasarkan total skor rata-rata yaitu 4,1 diperoleh kevalidan dengan kriteria sangat valid. Berdasarkan hasil validasi oleh ahli media dan ahli materi menyatakan bahwa CD Interaktif pembelajaran matematika pada materi statistika memenuhi syarat kevalidan untuk sebuah CD Interaktif.

b. Praktis

CD Interaktif yang dihasilkan telah memenuhi kriteria praktis berdasarkan hasil angket respon siswa. Secara umum tanggapan guru CD Interaktif yang telah digunakan dalam pembelajaran adalah baik dan tanggapan siswa adalah sangat baik. Sementara itu pelaksanaan proses pembelajaran yang diamati juga menunjukkan hasil yang sangat baik. Hal ini berarti bahwa CD Interaktif yang dikembangkan praktis. Berdasarkan hasil angket respon siswa yang diberikan oleh siswa diperoleh skor rata-rata 4,01 dari skor maksimal 5 dengan klasifikasi sangat baik dan praktis. Hal ini menunjukkan bahwa CD Interaktif yang digunakan membantu dan memudahkan siswa dalam memahami materi dan mengembangkan kemampuan komunikasi matematisnya. Hasil respon siswa terhadap CD Interaktif dan proses pembelajaran ditinjau dari aspek kemudahan dan keterbantuan menunjukkan bahwa tanggapan siswa terhadap pembelajaran menggunakan CD Interaktif yang telah dikembangkan sangat baik. Hal ini didasarkan pada respon siswa yang menunjukkan kategori sangat baik pada semua butir pernyataan.

\section{c. Efektif}

Berdasarkan hasil uji coba lapangan, CD Interaktif dengan menggunakan pendekatan kontekstual yang dihasilkan telah memenuhi kriteria efektif. Penilaian keefektifan dilihat dari hasil tes belajar siswa. Data tes hasil belajar siswa menunjukkan bahwa siswa yang mencapai kriteria ketuntasan minimal (KKM) nilai 70 sebanyak 28 siswa dari 32 siswa. Dengan demikian persentase ketuntasan siswa sebesar 87,5\% sehingga diperoleh keefektifan dengan kriteria tinggi. 
Berdasarkan hasil tes belajar diperoleh nilai rata-rata 80,6 dari skor maksimal 100 dengan klasifikasi baik. Ketercapaian hasil belajar menunjukkan tingkat ketercapaian tujuan pembelajaran sehingga produk yang dikembangkan dapat dikatakan efektif. Meskipun masih terdapat beberapa kekurangan dalam pelaksanaan pembelajaran kontekstual di kelas, secara keseluruhan pelaksanaan pembelajaran efektif ditinjau dari kemampuan komunikasi matematis siswa.

Tabel 3. One-Sample Statistics

\begin{tabular}{ccccc}
\hline & $\mathrm{N}$ & Mean & Standar Deviation & ;tandar Error Mean \\
\hline Nilai Akhir & 32 & 81.25 & 12.378 & 2.188 \\
\hline
\end{tabular}

Tabel 4. One-Sample Test

\begin{tabular}{|c|c|c|c|c|c|c|}
\hline \multicolumn{7}{|c|}{ Test Value $=70$} \\
\hline & \multirow[b]{2}{*}{$\mathrm{t}$} & \multirow[b]{2}{*}{$\mathrm{df}$} & \multirow{2}{*}{$\begin{array}{c}\text { Sig. } \\
\text { (2-tailed) }\end{array}$} & \multirow{2}{*}{$\begin{array}{c}\text { Mean } \\
\text { Difference }\end{array}$} & \multicolumn{2}{|c|}{$\begin{array}{l}95 \% \text { Confidence Interva } \\
\text { of the Difference }\end{array}$} \\
\hline & & & & & Lower & Upper \\
\hline $\begin{array}{l}\text { Nilai } \\
\text { Akhir }\end{array}$ & 5.141 & 31 & .000 & 11.250 & 6.79 & 15.71 \\
\hline
\end{tabular}

Tabel 3 dan tabel 4 merupakan hasil Uji Ketuntasan siswa dengan bantuan SPSS.

Dari tabel output uji homogenitas didapatkan nilai Sig. Nilai ini akan dibandingan dengan nilai signifikan 0,05. Dari hasil uji rata-rata satu pihak, maka peneliti menyimpulkan Sampel memiliki nilai Sig. $=0.000$. Jadi data sampel siswa kelas xi yang memperoleh pembelajaran matematika menggunakan CD Interaktif memiliki rata-rata pemecahan masalah lebih dari 70 .

Tabel 5. Group Statistics

\begin{tabular}{lllccc}
\hline & Group & $\mathrm{N}$ & Mean & $\begin{array}{c}\text { Standar } \\
\text { Deviation }\end{array}$ & $\begin{array}{c}\text { Standar } \\
\text { Error Mean }\end{array}$ \\
\hline $\begin{array}{l}\text { Nilai } \\
\text { Tes }\end{array}$ & Awal & 32 & 63.12 & 13.781 & 2.436 \\
\cline { 2 - 6 } & Akhir & 32 & 80.62 & 12.165 & 2.150 \\
\hline
\end{tabular}


Tabel 6. Independent Samples Test

\begin{tabular}{|c|c|c|c|c|c|c|c|c|c|c|}
\hline & & $\begin{array}{r}\text { Lev } \\
\text { Tes } \\
\text { Equa } \\
\text { Vari }\end{array}$ & $\begin{array}{l}\text { ene's } \\
\text { for } \\
\text { ity of } \\
\text { inces }\end{array}$ & & & & est for $\mathrm{E}$ & Equality & of Means & \\
\hline & & & & & & & $\begin{array}{l}\text { Mean } \\
\text { Differ }\end{array}$ & $\begin{array}{c}\text { Std. } \\
\text { Error } \\
\text { Differ }\end{array}$ & $\begin{array}{l}95 \% \\
\text { of the }\end{array}$ & $\begin{array}{l}\text { fidence } \\
\text { cval } \\
\text { fference }\end{array}$ \\
\hline & & $\mathrm{F}$ & Sig. & $\mathrm{t}$ & $\mathrm{df}$ & tailed) & ence & ence & Lower & Upper \\
\hline $\begin{array}{l}\text { Nilai } \\
\text { Tes }\end{array}$ & $\begin{array}{l}\text { Equal } \\
\text { varianc } \\
\text { es } \\
\text { assume } \\
\text { s }\end{array}$ & 2.553 & .115 & -5.385 & 62 & .000 & -17.50 & 3.250 & -23.996 & -11.004 \\
\hline & $\begin{array}{l}\text { Equal } \\
\text { varianc } \\
\text { es not } \\
\text { assume } \\
\text { s }\end{array}$ & & & -5.385 & $\begin{array}{c}61 . \\
06 \\
0\end{array}$ & .000 & -17.50 & 3.250 & -23.998 & -11.002 \\
\hline
\end{tabular}

Tabel diatas adalah hasil Uji Rata-rata Perbedaan nilai siswa dengan bantuan SPSS.

Dari hasil uji perbedaan rata-rata maka peneliti menyimpulkan bahwa hasil belajar sebelum kurang dari hasil belajar sesudah proses pembelajaran yang memanfaatkan CD interaktif lebih tinggi dari hasil belajar sebelum lebih baik dari pada sesudah proses pembelajaran yang memanfaatkan CD interaktif dengan Sig (2-tailed) = 0,000 0,05.

Secara umum uji coba media pembelajaran berjalan dengan lancar. Siswa aktif, antusias, dan bersemangat dalam pembelajaran menggunakan media pembelajaran CD interaktif ini. Penilaian keefektifan dilihat dari hasil tes belajar siswa. Data tes hasil evaluasi siswa menunjukkan bahwa siswa yang mencapai kriteria ketuntasan minimal (KKM) nilai 70 sebanyak 28 siswa dari 32 siswa. Dengan demikian persentase ketuntasan siswa sebesar 87,5\% sehingga diperoleh keefektifan dengan kriteria tinggi.

Peneliti membagikan angket respon kepada siswa untuk mengetahui bahwa produk tersebut dapat dinyatakan praktis atau tidaknya. Berdasarkan penilaian siswa diperoleh nilai rata-rata angket respon siswa sebesar 4,01. Hal tersebut berarti bahwa CD Interaktif yang dikembangkan dinyatakan praktis dengan kualitas baik.

Berdasarkan tercapainya kriteria valid, praktis, dan efektif dari CD Interaktif pembelajaran yang telah dikembangkan, maka diperoleh suatu produk akhir berupa CD Interaktif pembelajaran matematika pada materi statitika menggunakan pendekatan 
kontekstual yang valid, praktis, dan efektif sehingga layak digunakan dalam pembelajaran.

Penelitian ini sejalan dengan Risqi, H. (2016), di mana CD interaktif praktis dan efektif digunakan dalam pembelajaran matematika untuk meningkatkan kemampuan pemecahan masalah siswa SMP. Hal ini dikarenakan CD interaktif yang dikembangkan dapat memberikan respon positif bagi guru dan siswa serta dapat mencapai ketuntasan dalam hal kemampuan pemecahan masalah siswa. Hasil yang diperoleh ini sesuai dengan hasil penelitian Asikin, M. (2008), di mana pembelajaran yang menggunakan bantuan CD interaktif dapat mencapai ketuntasan belajar siswa. Hal ini dimungkinkan karena siswa dapat belajar mandiri di rumah dan saat di kelas mereka dapat berperan aktif dalam kegiatan pembelajaran untuk memecahkan masalah yang ada pada CD interaktif. Mereka termotivasi dan merasa senang dengan tampilan CD interaktif yang menarik sehingga mereka tidak merasa bosan dalam belajar matematika.

\section{SIMPULAN DAN SARAN}

Berdasarkan hasil penelitian dan pembahasan di atas dapat diambil kesimpulan sebagai berikut;

1. Hasil pengembangan CD Interaktif pembelajaran matematika pada materi statistika di kelas XI SMK Bhakti Praja 2 Batang valid.

2. Hasil pengembangan CD Interaktif pembelajaran matematika pada materi statistika di kelas XI SMK Bhakti Praja 2 Batang praktis.

3. Hasil pengembangan CD Interaktif pembelajaran matematika pada materi statistika di kelas XI SMK Bhakti Praja 2 Batang efektif.

\section{DAFTAR PUSTAKA}

Arief S. Sadiman, dkk. (2009).Media Pendidikan. Jakarta: Rajawali Pers.

Asikin, M. (2008). Pengaruh model pembelajaran matematika creative problem solving (CPS) berbantuan CD interaktif terhadap kemampuan pemecahan masalah pada siswa SMA kelas X. Lembaran Ilmu Kependidikan, 37(1).

Fuad Ihsan. (2001). Dasar-Dasar Kependidikan.Jakarta: Rineka Cipta.

Prastowo, Andi. (2011). Panduan Kreatif Membuat Bahan Ajar Inovatif. Jogjakarta: DIVA Press. 
Pribadi, Benny A. (2009). Model Desain Sistem Pembelajaran. Jakarta: PT. Dian Rakyat.

Risqi, H. (2016). Pengembangan Meida CD Interaktif Matematika Untuk Meningkatkan Kemampuan Pemecahan Masalah Siswa SMP. Refleksi Edukatika: Jurnal Ilmiah Kependidikan, 6(1).

Sudjana, Nana. (2005). Penilaian Hasil Proses Belajar Mengajar. Bandung: PT. Remaja Rosdikarya.

Suherman, Erman., dkk. (2003). Strategi Pembelajaran Matematika Kontemporer. Bandung: JICA.

Sugiyono, 2008.Metode Penelitian Kunatitatif Kualitatif dan R\&D. Bandung: Alfabeta. Sugiyono.(2012). Metode Penelitian Pendidikan. Bandung: Alfabeta. 